European journal of American studies

Summer 2015, including Special Issue: (Re)visioning America in the Graphic Novel

\title{
Vanishing Point: Joan Didion and the Horizons of Historical Knowledge
}

Kenneth Millard

\section{OpenEdition}

\section{Journals}

Electronic version

URL: https://journals.openedition.org/ejas/11086

DOI: $10.4000 /$ ejas. 11086

ISSN: 1991-9336

Publisher

European Association for American Studies

Electronic reference

Kenneth Millard, "Vanishing Point: Joan Didion and the Horizons of Historical Knowledge", European journal of American studies [Online], 10-2 | 2015, document 16, Online since 14 August 2015, connection on 08 July 2021. URL: http://journals.openedition.org/ejas/11086 ; DOI: https://doi.org/ 10.4000/ejas. 11086

This text was automatically generated on 8 July 2021.

Creative Commons License 


\title{
Vanishing Point: Joan Didion and the Horizons of Historical Knowledge
}

\author{
Kenneth Millard
}

All the influences were lined up waiting for me. I was born, and there they were to form me, which is why I tell you more of them than of myself. Saul Bellow, The Adventures of Augie March, 43.

1 It is widely accepted in contemporary criticism that we cannot know history in any conventionally authentic sense-we can only construct narratives of history that are contingent upon the forms of their representation. History does not exist in any unmediated form, anterior to the rhetorical and linguistic styles of its production, and therefore "the object of history is whatever is represented as having hitherto existed" (Hindess 69). In the complete absence of access to authentic historical knowledge, we can only study the representation of history, that is to say, those narrative and aesthetic forms that constitute history's mediation. Hence Fredric Jameson's often quoted declarations concerning "the crisis of historicity itself" (Bloch 198) and "the disappearance of the historical referent" (Jameson, 1991, 25). Such a loss reduces history to aesthetics and seems to evacuate politics and ethics in favor of a postmodern relativism, the consequences of which have been widely elucidated. Novelists themselves were quickly alert to the radical possibilities of these developments. E. L. Doctorow, for example, argued that "there is no fiction or nonfiction as we commonly understand the distinction: there is only narrative" (Doctorow 231). All knowledge is a form of narrative, and this appears to reduce history to forms of radical contingency, where nothing can be known that is anterior to the linguistic styles of its production and composition.

These developments in critical thinking have had wide-ranging consequences. For example, critics have been concerned to examine the implication of the epistemological issues raised by the perceived collapse of a distinction between history and fiction. If 
everything we can know is simply a function of the (compelling) aesthetic styles by which it is contrived, then there is no authentic foundation for history (or politics and ethics). The concept of authenticity itself becomes merely another semantic unit in the linguistic turn. As Tony Bennett expressed it, "If narratives are all that we can have and if all narratives are, in principle, of equal value...then rational debate would seem to be pointless" (54). This apparent impasse has found a variety of critical responses (each with its own conceptual vocabulary) that attempt to address the radical indeterminacy that Bennett identifies.

This article on Joan Didion examines some of those responses as conceptual methodologies for thinking about Where I Was From and the representation of Western history. Didion's memoir has numerous significant points of historical origin, each with its respective claim to authority, but the structure of her book does not necessarily privilege any one above the others. Thus the structure and style is an important aspect of this memoir's contribution to conceptualizations of history and fiction in the contemporary American West. Where I Was From is a work that seeks not only to retrieve history but to engage a politics of history that might have some critical purchase on social change. If we understand the memoir as "personal history that seeks to articulate or repossess the historicity of the self" (Hart 491) then Didion's book can be recognized as a significant contribution to our knowledge of how subjectivity is informed by the politics of Western historical discourse. While significant changes in critical thinking belong to the historical moment of post-structuralism, it is also true that fiction of the American West has often had a particularly close relationship to the discipline of history. However far back we trace the fictional and nonfictional origins of fiction of the Western frontier, to The Virginian, or Roughing It, The Last of the Mohicans, Letters From An American Farmer or Mary Rowlandson's captivity narrative, such fiction can be understood as emerging from forms of historical discourse that have closely informed it. Further, such fiction has often been evaluated in terms of its historical veracity, as if it was a kind of nonfiction itself, and as if history was the definitive standard of its appraisal. Also, fiction of the American West is itself often interested in dramatizing the conceptual problem of the origin-where does our hero come from, and how does this figure's unknown history shape the narrative we read? Western fiction has characteristically been engaged in exploring the historicity of its characters in ways that are reminiscent of post-structuralist theories of history.

4 For example, there is an excellent short story by Claire Watkins called "Ghosts, Cowboys" which is structured in terms of several different ways of beginning. The story's narrator begins at numerous historically diverse moments, ranging from the founding of Reno, Nevada, in 1859 , to the present day, as part of a narrative project in which she seeks to understand herself and to identify the key point at which her present predicament might have begun. How far back can she go, and how persuasive does she find each of these putative alternative beginnings as a fulfilling account of where her contemporary history began? The story is thus structured by phrases such as "Here is as good a place as any," (3), and "We might start with," (7), and "Or here. Begin here." (9). The narrator asks herself: where does my present history truly begin, and finds that "At the end, I can't stop thinking about beginnings" (1). Such etiological enquiries are characteristic of Watkins's collection Battleborn (2012), as if to concur with T. S. Eliot in Four Quartets, "In my beginning is my end." (196). These kinds of historical enquiry are especially characteristic of Western short fiction by William Kittredge, Annie Proulx, Maile Meloy and Poe Ballantine, where the ruptures of 
deracination, migration and historical discontinuity become integral to the subjectivity of contemporary characters who find themselves adrift. The challenges associated with establishing a valuable and sustaining sense of historical connection are often central to a Western fiction that locates itself as violently stranded between an unknown or repudiated past and an indeterminate future. The characters of Western short fiction are typically frozen in liminal moments, emerging from some broader historical predicament into a contemporary crisis that is pregnant with a sense of its own future. Watkins's story concludes with a quotation from Gregory Peck in the movie Duel in the Sun, "I always have so much to remember" (23).

5 Where I Was From is similarly etiological: it traces history back to originating points that can be scrutinized for the political efficacy of the narratives they initiate. Such points are always themselves the products of an antecedent history that might also be examined in an ever-receding horizon of historical knowledge. Simultaneously, Didion's own methodological practices have their origin in her consciousness of women's history, such that the style of her memoir, its unique aesthetic character, is derived from a tacit feminist stance which, like full historical awareness, is just at the limit of her critical consciousness. It is not the purpose of Didion's memoir to resolve such contradictions but to create a text that demonstrates the continuing value of protestant religious ideology to the origins of Western history, and to provide a compelling autobiographical account of the gender politics of its legacy.

6 Where I Was From begins in 1766 with a single remarkable long sentence that provides a compressed account of Didion's maternal ancestor, Elizabeth Scott, and summarizes years of history in a couple of dozen words. It is a literal point of beginning for Didion's text, although of course this ancestor must have had an antecedent history, the parents (not remembered) who brought her to the Virginia frontier in the first place. The account of this woman's history is a place for Didion to begin. Yet not only does the rest of her memoir suggest that this is only one such starting point, but even here there is a skepticism and provisionality about definitive points of beginning. Didion's memoir is structured partly by skepticism about origins that are located in dramatic accounts; Elizabeth Scott's husband was said to have killed ten men: "This may be true or it may be, in a local oral tradition inclined to stories that turn on decisive gestures, embroidery" (Didion 3). There is a self-conscious wariness about understanding history as having originated at decisive moments, because such moments may be simply a matter of style, oral tradition favoring the dramatic aesthetic technique of "decisive gestures." There is also an awareness that such moments have their own antecedent history, which is, in turn, a further putative point of origin. Where do such problematic distances of historical knowledge lead? Didion's information here comes "on the word of a cousin who researched the matter" (3), which suggests both the contingency of this kind of knowledge, and the vertiginous horizons of its historical sources.

7 A further crucial point of origin for Didion is the great migration of the 1840 s, or as she expresses it, "Child of the crossing story that I was" (217). Didion was born in 1934, and yet understands herself as the heir to the ideological legacies of the "crossing story" mythology that emerged in the 1840s. The crossing story has been conventionally mythologized as one of America's founding epics-as the origin story of Anglo-American migration across the North American continent from Missouri to California and Oregon. These migrations in the 1840s involved hundreds of thousands 
of "pioneers" and generated a mythology of migrant heroism and conquest that contributed significantly to the ideology of American exceptionalism, confirming and augmenting the belief in manifest destiny and giving fundamental support to the quasibiblical narrative of US colonization. But while the crossing story has entered the popular American consciousness as a demonstration of the power of romantic individualism, recent scholarship has tended to unpick the account of how the West was won, to examine more closely its costs and losses, and to present a narrative that is closer to what purports to be historical authenticity, and a little further from moral fable. Didion's memoir should be recognized as part of this historical revision.

8 It is significant that Didion's most explicit expression of allegiance to the legacy of the crossing story is made at a moment in her relationship with her mother. Didion's mother is reminded suddenly and poignantly of the death of her husband. Joan Didion flees this scene of distress, leaving her mother to her grief. Retrospectively Didion interprets this "abandonment" (217) as typical of those historical ruptures and violent departures that characterized the necessary exigencies of Westward movement, even to the point that she dramatizes leaving her mother on the occasion of a massive snow storm. This quite deliberately invokes the snowfalls in the Sierra Nevada Mountains that were a life-and-death Rubicon for the wagon trains of the 1840s. Didion's selfdramatizing has an artfully performative aspect that is demonstrably staged to align her with crossing story mythology. Didion depicts herself as escaping before the passes are closed, and in so doing she survives. But she also recognizes retrospectively that to flee the traumatic scene of her mother's grief is to establish a scene of abandonment that she will later understand as a further point of origin for another traumatic narrative. Didion's memoir never relinquishes this figurative language of the crossing story, only repeats it. The memoir's very last lines continue to invoke this history: "I was still pretending that she would get through the Sierra before the snows fell. She was not" (226). Didion thus depicts herself as a survivor, but she also asks, "when you survive that way-do you really survive at all?" (37).

9 There is no sentimentality in Didion's depiction of leaving her mother, just a terse economy of understatement: "There was no believable comfort I could offer my mother," and many years later, the chapter concludes, "I remembered this abandonment the day she died" (217). The moment that she previously repressed returns to haunt her. Such abandonments, Didion believes, are integral to the crossing story; any guilt she might experience retrospectively is understood as subordinate to the powerful frontier ethic in which she was raised. Abandonments were the dark underside of crossing story mythologies: mothers abandoned children in the wilderness within hours of their deaths, and had already abandoned families at home in order to light out West in the first place. Such sacrifices were simply necessary to the imperative of restless Westward movement, to a compulsive narrative of Western progress that was somehow inevitable, ordained, manifest. This is the outlook that Didion regards herself as having inherited, and she understands her contemporary moment as vitally shaped by its ideology: "never take no cutoffs and hurry along as fast as you can" (199). This quotation, from the pioneer Virginia Reed, is repeated throughout Didion's memoir $(75,160,199)$ along with a quotation from another woman, Sarah Royce, who occupied the wagon train: "The blank dreariness. Without house or home" (208). These italicized quotations from less well-known women of the wagon trails are situated and repeated as central to Didion's own memoir, as vitally important to understanding the legacy in the contemporary moment. Didion thus positions herself 
as heir to a specifically female legacy of the crossing story and aligns herself with the women who paid the price of the heroic marches Westward. This, she suggests, was an invidious ethic of "progress" that begins with deracination and then commits itself to a series of abandonments, ruptures and painful discontinuities that Didion now regards as radically anti-historical. The function of her memoir is thus to recover a different narrative of history, one that might trace itself back to an alternative origin and thereby retrieve a different political and social history, one that has the experience of women closer to its origin.

10 The final chapter of Where I Was From is a further point of origin, even though it appears at the end. This account of the death of Didion's mother is the origin of the text that we have been reading, the separation from the mother that occasions a crisis of origins for Didion which compels her to write this historical account of herself: "who will remember me as I was, who will know what happens to me now, where will I be from?" (204). The confusion of tenses in that last phrase epitomizes the challenges of Western American history: what future can the individual have when the past is abruptly lost or violently severed? The memoir's title Where I Was From is part of the creative response to that question, posed at the originating moment of the self in its separation from the mother. It is the death of her mother that occasions Didion's examination of "the confusions and contradictions in California life" because she regards her mother as exemplifying them so well (204). It is not Didion's father who exemplifies the quintessential Western ethic. Didion's father, unlike her mother, Eudene, is not named. Didion's father suffered badly from depression, and became a client of a female psychiatrist who was very helpful to him because, he said, "We talked about my mother" (214). Separation from the mother then is not only vital to understanding a sort of commitment to frontier expansion but also to the history of the West, which is figured by Didion as a compulsive repetition of separation and abandonment that permanently traumatizes its citizens. Didion herself repeats the phrase "never take no cutoffs" several times in her memoir, and this repetition is itself to be understood as an inability to mourn. Where previously Didion had abandoned her mother, now she is abandoned by her, and these crises in her relationship with her mother are vital to understanding a Western history which fostered a masculine ethic of urgent progress: "Were not such abandonments the very heart and soul of the crossing story...Bury the dead in the trail and run the wagons over it?" (198-99).

11 Yet even when Didion attempts to free herself from the myth of origins, she falls into a similarly patterned mythic structure, thus demonstrating the inescapability of textuality in the experience of history. For example, Didion's memoir gives her mother's death (but not her father's) its specific date as a vital point of origin, both for history and for the act of writing. To augment the sense of a specifically matrilineal genealogy that began with Elizabeth Scott in 1766, Didion also identifies a crucial experience with her daughter that is central to how she understands Western history: "Later it seemed to me that this had been the moment when all of it...the entire enchantment under which I had lived my life-began to seem remote" (219-20). This further moment of historical origin can again only be recognized retrospectively, and it is brought about by a consciousness of the discrepancy between the simulations of old Sacramento and the authentic reality of her own (adopted) daughter Quintana, between the false consciousness of "enchantment" and the contemporary reality of a daughter who has no meaningful connection to the old Sacramento spectacle of history. This moment of disenchantment is itself a moment of origin, and it is created 
retrospectively as an imagined memory. I propose reading it as a (momentous) text, and Didion as a textual critic of its salient features. This moment of revelation, of the full recognition of her daughter in history, is one in which Didion is herself redeemed from historical narratives of the West that seemed to doom her to a personal history of traumatic abandonments and disruption; she is also redeemed from the false consciousness of nostalgia through her knowledge of her daughter in the presence of the historical simulations of old Sacramento: "It was only Quintana who was real" (219). This experience of authenticity was vitally important to Didion's historical consciousness, but as soon as Didion commits her epiphanic memory of Quintana to language (that is to say, to recognize it historically), then it becomes part of the textuality of history regardless of the putative authenticity of its origin. It thus dramatizes the inevitable fall into potentially duplicitous historical language that is attendant upon a faith in fundamental or determining moments of origin. This is precisely the kind of dramatic scene that Didion treated with caution in the history of Elizabeth Scott, and yet emulates here (and in the memory of her abandonment of her mother). In the creation of compelling historical narratives (such as we might expect in a memoir) it seems that Didion is still heir to "a local oral tradition inclined to stories that turn on decisive gestures" (3). We might provisionally conclude that the fall into historical language is inescapable; it has to begin somewhere, and all we can do is worry over the politics of its beginnings.

Didion's memory of her daughter Quintana is necessarily contingent upon the vicissitudes of memory's textual representation. Writing this memoir about Western history cannot entirely escape the textuality of history that it scrutinizes so skillfully. Yet it does evince a faith in the authenticity of women's experience. With Quintana, Didion sees the chain of inheritance as having been broken; the mother does not pass on to her daughter the damaging Western ethic, and thus the cycle of trauma might be broken. Such a faith in women's experience is seen also in textual women like Virginia Reed and Sarah Royce, whose writing holds out the possibility of providing a counternarrative of redemption from pernicious nostalgia, and from a traumatic and ahistorical conceptualization of true origins. As this article will argue, these issues have their own origins in the biblical conception of Eve as the cause of the Fall, as the ruin of Adam and the agent of his expulsion into a corrupt world from which he must seek redemption. Eve's role in history is thus denigrated in the Western mythology that Didion's memoir scrutinizes, and her challenge, partly, is to retrieve its origins and its historical narrative as a corrective to the legacy of traumatic abandonments that she has inherited.

13 Feminist appraisals of mythology and temporality might seem inappropriate to the study of Joan Didion. In an interview in the 1970s she repudiated feminism unequivocally in favor of a "western frontier ethic" that she clearly did not understand as a form of masculinist discourse: "I never had faith that the answers to human problems lay in anything that could be called political...the ethic I was raised in was specifically a Western frontier ethic, that means being left alone and leaving others alone" (Davidson 14-15). This anti-social belief in the sovereign individual does not acknowledge the extent to which characters are informed by their social and political contexts, and seems all the more surprising because Didion's early fiction (Run River and Play It As It Lays) depict in compelling terms the anguished predicaments of central women characters who are the victims of patriarchal culture. Yet these women eschew, sometimes infuriatingly, the opportunities of feminist thinking. There is a clear 
awareness in these novels of the possibilities of feminist politics, and they are amenable to feminist readings. Although Maria Wyeth (for example) does not espouse feminist views, the novel in which she is the protagonist is clearly alert to the patriarchal nature of the cultural discourses that determine her life and her acting career. It is this tension that makes Didion's early fiction so subtle. Marilyn Maxwell describes the "narcissistic" nature of Didion's early heroines, and believes that their failure to be self-reflexive about their social positions "may reflect the self-indulgent inertia of a pampered middle-class woman" $(56,61)$. Thus the class politics of Didion's early heroines are at odds with their social positions as women, and Didion's reluctance to recognize the importance of gender seems anomalous in novels of the late 1960s and early 1970s.

14 The version of the American Adam in which Didion expressed faith was classically formulated by R. W. B. Lewis in 1955 as "an individual standing alone, self-reliant and self-propelling, ready to confront whatever awaited him with the aid of his own unique and inherent resources" (5). Lewis's thesis has implicit investments in class and gender that are products of their own (Cold War) historical moment, yet his book delineated the emergence of a powerful and seductive mythology of original innocence, of repudiating history in favor of an ideology of new beginnings, that was fundamentally ahistorical. The United States in this view "was not the end-product of a long historical process...it was something entirely new" (5). Lewis identified his own point of origin in Hawthorne's "Earth's Holocaust," which dramatizes "the need for a purgatorial action" (14) that precipitates the birth into an erroneous mythology of the quintessentially male American citizen. This (constant and recurring) desire for purgatorial action is a further textual source for the mythology of Westward expansion that Didion's memoir scrutinizes. It is a drive to repudiate history and to subscribe to a belief in new beginnings. This desire was a utopian impulse, originally born of a specific Protestant religious ideology, a belief that redemption from original sin could be achieved by the errand into the wilderness. The desire to be reborn in the West renounces history as sin, or converts it into the belief in the possibility of being born again in the New World to great beneficial effect (spiritual, social, material). In terms of national mythology, this faith in the end of history marks the providential chosenness of these (American) people in this (promised) land. Thus the divine purpose of English Protestantism made the renunciation of history necessary, and redemption from the fall was integral to the mythology of westward expansion. In this context, Didion's search for a transcendental origin that acts as a guarantor of historical meaning is perhaps analogous to the attempts at the hermeneutic recovery of the True Word, which had been obfuscated by generations of misrepresentation, or, as Anders Stephanson expresses it, "buried as it had been under vast layers of interpretative falsification during centuries of popish heresy" (8). Didion's commitment to re-reading, with such tact and close attention to language, is a secular version of the competent exegesis of sacred texts, but not one that shows an awareness of its historical origin in religious ideology.

15 Where I Was From is thus committed to the search for an authentic origin of America in the textual swamp of historical narratives that constitute it, and to the recovery of a point of origin that holds out the possibility of a different politics. Didion's memoir critiques the ideology of western expansion because it is founded (for her as a woman) on a false concept of the origin to begin with, and it is her lingering apprehension of the concept of original sin that gives her memoir its abiding and consistent curiosity about definitive points of origin. The very genre of the memoir itself, and especially 
one as critically self-reflexive as Didion's, has its genealogy in the Puritan spiritual responsibility for self-inspection. Didion's text has its generic origins in vigilant Puritan self-examination, in the search for the sacred covenant between the individual and the Word, and in anxieties that it might have been, along the way, misinterpreted. Hence the vital importance of the fastidious interpretation of texts: learning how to read "correctly," and how to understand the proper narrative of history, is crucial to her project because it contains the possibility of revealing the true and original Word. In this context we might usefully understand Didion's memoir as a form of American jeremiad, lamenting the fall away from an original experience of grace, and, like nostalgia, a narrative of desire for aspects of a putative historical past that have been tragically lost. It might appear that the desire for a state of grace can only be fulfilled through the close textual scrutiny of historical documents, a process that traps her in the very myth of origins that she is eager to escape. But in returning to sources to unpick their masculine bias, Didion recovers and articulates a counter-history that puts women's experience at its origin, just as her memoir puts her own history with her mother and her daughter at its heart.

16 In a recent book that returns to Lewis's American Adam for its own point of origin, Jonathan Mitchell's Revisions of the American Adam offers a combative appraisal of the gender politics of this American mythology: "it is not simply in opposition to women that men become American, but through the destruction of the feminine as the representative of the cause of the fall, Eve" (25). The purgatorial action of Hawthorne's "Earth's Holocaust" then, is the repudiation of the feminine that constitutes the foundation and genesis of the authentically American male, and the origin of the mythology of Western expansion which, as a masculinist discourse, is by its very nature inimical to women. Or, as Didion expresses it, "Each traveler had been, by definition, reborn in the wilderness...the very decision to set forth on the journey had been a kind of death" (29). This death is not "innocent," but according to Mitchell, it is a murderous rage against the feminine by which American masculinity was constituted. Further, any such "decision" is the end product of the antecedent history that produced or created it, and therefore needs to be historicized itself, an issue that many scholars of the crossing story (such as John Unruh and Frank McLynn) find especially difficult to resolve. How might we historicize the desire for "a kind of death"? Frank McLynn argues that "majority opinion until the 1840s held that to travel overland to California or Oregon was virtually to commit suicide" (19). If the sacrifices of the crossing story were necessary to achieve a form of redemption, then the central question of Didion's memoir becomes "for what exactly, and at what cost, had one been redeemed?" (37).

17 Among dozens of shrewd textual analyses, Didion's memoir includes readings of Frank Norris and Jack London that show how "purgatorial action" (understood as the violent repudiation of the feminine) is responsible for a pernicious social politics that is based on a willful denial of authentic historical knowledge, on a politically motivated amnesia. In her choice of texts, Didion is drawn to ambiguity, and to the lack of resolution of major ideological features in her chosen narratives. Norris's The Octopus (1901) is therefore "A troubling work" (43) and "a deeply ambiguous work" (44), and even the result of a "deep and troubling confusion" (48). London's The Valley of the Moon (1913) is similarly characterized as full of contradiction, and as complicit in "a willful revision" of "the moral ambiguity of the California settlement" (75). It is precisely such 
ambiguity that attracts Didion's particular skills as a shrewd and perceptive textual critic.

18 Crucially, Didion's hermeneutic methodology has its origin in her characterization of her mother: "In the aftermath of my mother's death I found myself thinking a good deal about the confusions and contradictions in California life, many of which she had herself embodied" (204). As a critic, Didion's critical practice of teasing out ambiguity, examining gaps and silences, is derived from her understanding of her mother. Reading her mother gives Didion the strategy for the critical examination of her culture, and tracing her mother's origins back to 1766 gives her an opportunity to re-read Western history. Didion's memory of her mother facilitates her practice as a scholarly and critical reader. This is a vitally important point of origin for Didion's sense of a history that is counter to the biblical denigration of Eve. Didion is drawn to texts where she can see her mother embodied, and her textual exegeses become contemplations of her mother's character and its relation to conceptualizations of the history of the West. Didion's mother could be "passionately opinionated" about issues that reflected "no belief she actually held" (205), and this tendency Didion comes to understand as "a barricade against some deep apprehension of meaninglessness" (207). Such an apprehension is perhaps a tacit consciousness of the unexamined nature of a commitment to purgatorial action that is of no value to women because it is the expression of a profoundly patriarchal religious ideology which, in its belief in the centrality of the renunciation of original sin, locates that sin in women, in Eve. When one's life is predicated on a recurring commitment to the necessity of repudiating history, then the idea of that life as a purposeful teleological process is reduced to amnesia and despair, or to what Didion elsewhere terms "this localized nihilism" (69). As Adrienne Rich once wrote: "It's a very old American pattern, the pattern of the frontier, the escape from the old identity, [but] too much of ourselves must be deleted when we erase our personal histories and abruptly dissociate ourselves from who we have been" (143). Didion admits that the women in her family were "given to breaking clean with everyone and everything they knew" (7), and she recognizes despair and futility in "a blinding and pointless compaction of stitches" in the quilt that her greatgreat-grandmother completed during the crossing "somewhere in the wilderness of her own grief" (6). Yet this quilt survives in Didion's home as an aesthetic artefact that is testimony to women's history, and therefore acts as a valuable record and reminder of a differently-gendered story. Didion's memoir thus creates a feminist aesthetic of history from its own dense imbrication of textual stitches, an aesthetic artefact with a unique style that helps redeem history from amnesia. It is a text that helps to assuage the existential despair caused by the radical anti-historicism of her Western cultural inheritance.

19 In the context of conceptualizations of history and gender, Didion's reading of Faulkner is especially valuable. Like her other texts, Faulkner's "Golden Land" is useful to Didion precisely because the story "does not entirely hold up" (95), and the structure of its unresolved ideological issues makes it interesting. "Golden Land" is a satire on the decadence of California, and it uses the western history of the mother as a counterpoint by which to establish contemporary declension. The fall into modernity here is expressed partly through the promiscuity of the daughter, "April Lalear Bares Orgy Secrets" (Faulkner 705), and partly through the cross-dressing of the son, who is named Voyd as if to confirm his cancelled status. Both daughter and son steal from their grandmother, Samantha Ewing, because they are the corrupt products of a 
decadent culture that has never known hardship or struggle. This decadence is established principally by means of a counterpoint with the moral probity of Samantha, whose integrity was earned by a specific historical narrative of the frontier: "The generation before that they were born in a sodroofed dugout on the Nebraska wheat frontier. And the one before that in a log house in Missouri. And the one before that in a Kentucky blockhouse with Indians around it" (724). This flimsy, and perhaps even fanciful, historical sketch is held up by the story as the authentic narrative of moral probity which now attaches exclusively to the mother-figure, and is used as the means by which to satirize contemporary decline. Samantha Ewing is the paragon of moral virtue because she is associated with a history that the story valorizes as hard-earned and authentic.

20 But it is clear that the story indulges in nostalgia for a concept of moral value that has dubious historical origins. It is a history that is contrived solely for the purpose of the satire of the present moment, projected back on the frontier as a means to invest it with an idea of ethical virtue from which the contemporary West has departed; it is something "which she had gained by bartering her youth and strong maturity against the Nebraska immensity" (725), in other words an appeal to the landscape as the source of moral value. The heroic narrative of mother Ewing's moral goodness is derived from an untrustworthy history that is principally the product of a contemporary western culture that laments its own decline, and which requires a nostalgic historical opposition through which to establish that tragic declension.

21 It is especially interesting that the mother is the character against whom modernity's corruption is defined. Where Samantha Ewing's history and genealogy are crucial to the provenance of moral value, the story's enigmatic conclusion finds her stranded between life and death, where conceptualizations of history are firmly located in the woman's subjectivity. Samantha has saved enough money to return to Nebraska to die, but finally speculates that she might remain in California and "live forever" (726). This temporal scene locates historicity in the consciousness of the mother and invites a gendered reading of understandings of history as being all about Eve. The end of the story depicts her "looking at the clock" and contemplating "the changeless monotonous beautiful days without end countless out of the halcyon past and endless into the halcyon future" (726). "Golden Land" is a story about recognizing the relationship between women, historicity and ethics, and its value to Didion is not simply that it examines the mythology of western pioneers, but that it centrally locates historical consciousness in the figure of the mother. Previously, Didion had identified her ability to read western history through the critically-revealing contradictions of her mother, "which she had herself embodied" (Didion 204). Didion's identification of this particular story is therefore especially apposite to her memoir's larger thesis about the gender of western history.

22 For Didion, Faulkner's story "opens the familiar troubling questions" (95) about how myths are constructed and maintained. Although Didion designates her book as a memoir it is also clearly an enquiry into the functioning of myth, and especially a critical investigation of how myth functions as a crucial point of origin for California culture. The Lakewood analysis that follows Didion's brief reading of Faulkner is positioned structurally to demonstrate that the ideology of the myth is actually produced by American citizens who invest in it deeply, and thereby make its abstract texts integral to their material lives. The association of myth with origins is a 
significant one; as Percy Cohen has argued: "the greatest myths of our civilization are concerned with beginnings, with a moment in time in which a series of events is anchored-to locate things in time creates a far more effective device for legitimation than simply creating a set of abstract ideas which are timeless" (350). This idea of the social politics of origin myths is a central part of Didion's critique, and it is important to recognize that such myths, although they are a form of historical fiction, are nevertheless "stories that are not merely told but actually lived" (Mali 6).

23 Therefore Didion's remarkable segue from the Faulkner story of 1935 to the community of Lakewood, California in the 1990s, serves to demonstrate how western American history is still imagined as male and still understood as holding out the possibility of heroic male values that energized westward expansion. This promise of social fulfilment is nostalgically configured in the contemporary moment to keep alive the utopian vision that the Puritans might have recognized. Didion sees the repetition of this history in Lakewood's decline because it was predicated on the exaggerated valorization of a version of male historical progress and "the idealization of adolescent males" (115) and a social history founded on "the encouragement of assertive behavior among male children" (117). In Lakewood, the failure of this history results quickly in sexual violence. It is a contemporary reading of an American social culture which is deeply patriarchal and which inherits profoundly the legacies of westward expansion. As one adult protagonist in the Lakewood drama complained "I want to be in the ninth grade again...I want to go back to the wonderful days" (127), a nostalgic view of history that is not simply delusional and infantilizing but which contains "the arrogance and contempt for young women" which is its necessary corollary. Didion's critique adroitly connects the violence of Lakewood's decline to the military-industrial complex and the closure of California's aerospace plants, thus giving her analysis of Western masculinist history its connection to globalization, empire and imperialism. Where manifest destiny helped conquer the West, now it might conquer the world through the labor of "the last of the medieval handworkers...in the cathedrals of the Cold War" (136). Thus nostalgia and utopia converge in a quintessentially American condition of perpetual becoming, where, like mother Ewing in Faulkner's story, it seems possible to "live forever"-at least for boys in the ninth grade.

24 The term "nostalgia" has become an important part of the conceptual vocabulary of the contemporary study of history. For Susannah Radstone nostalgia has been "accorded a central position in debates concerning the rise of 'memory' in contemporary or postmodern Western culture" (116). Geoffrey Cubitt has made similar claims for "memory studies," arguing that there is a recent urgency to valorize memory as "an alternative historiographical discourse" (3). Like memory, nostalgia might be counterfeit, but that is not as important as its abiding value to the character of the contemporary moment. Nostalgia is conventionally a profound emotional investment in something deemed to be lost, or separated from, and that investment is itself a telling response to the perceived declensions of the contemporary period. Nostalgia is thus an expression of discomfort with the present moment's circumstances, one that creates an imaginary past as fantasy recourse to an historical sanctuary that offers some form of Edenic restoration.

25 Unlike the jeremiad (a respectable literary genre), however, the term "nostalgia" has acquired strongly negative connotations, especially since Fredric Jameson's article "Nostalgia for the Present," which was very influential in situating the term for 
postmodern theory. But Michael Roth is one of a number of critics who has written about the importance of the pleasure that nostalgia (understood as an illness) can offer: historically "the satisfactions available to the nostalgic adult came only through the illness; patients did not want to give up the gratification of their symptoms" (29). Even before Jameson's influential article, David Lowenthal's conception of nostalgia was more cautious about making simple value-judgments: "it is wrong to imagine that there exists some non-nostalgic reading of the past that is by contrast 'honest' or authentically "true" (30). Such arguments show that the word "nostalgia" has commonly acquired negative connotations, and even perhaps that Jameson is himself nostalgic for a narrative of the past that is less inauthentic than the ones he characterizes in postmodern culture. Jameson's article (reprinted as chapter nine of his Postmodernism, or, The Cultural Logic of Late Capitalism) is an analysis of the representation of history in Philip K. Dick's novel Time out of Joint (1959), and, simultaneously, an interpretation of the history of the novel's own unique moment of publication. Jameson uses Dick's historical fiction to prosecute arguments about how we understand the historicity of fiction, and the subtleties of the problem of history as a fictional narrative. While Jameson is not nostalgic for a lost model of authentic historical knowledge, he asks whether it is possible to retrieve some conceptualization of history from the vicissitudes of its textual representation, partly in order to reinstate its political importance. Is this possible after post-structuralism, or is this very project itself nostalgic?

$26 \mathrm{~A}$ good deal of recent feminist criticism has been dedicated to addressing this conceptual issue, and to investigating the absence of a gendered inflexion to examinations of historical knowledge. Works such as Cathy Caruth's Unclaimed Experience (1996), Marianne Hirsch's Family Frames (1997), Rita Felski's Doing Time (2000), Susannah Radstone's The Sexual Politics of Time (2007), Alessia Ricciardi's The Ends of Mourning (2003), Nancy Peterson's Against Amnesia (2001) and Susan Stewart's On Longing (1984) might be understood as a broad cultural attempt to recover a politics of history (or from history) after post-structuralism, from the prevailing sense that history was only a function of the rhetorical "protocols" of Hayden White's Metahistory and Michel Foucault's discourse theory. The concept of nostalgia especially has attracted attention from critics eager to scrutinize the politics of how temporality is conceptualized and gendered.

27 For example, we can see Didion's fidelity to a tentative feminist history in her antagonism to Jane Hollister Wheelwright's The Ranch Papers, which she criticizes for its nostalgia, because it "remains reluctant to confront the contradictions" that are integral to its view of history (Didion 57). Wheelwright's memoir is incapable of that form of critique because it is obedient to the authority of the father (from whom she inherited vast tracts of land), and can only ever be the story of "the daughter who reveres him" (58). Reverence and obedience are not conducive to the critical investigation of history. If traditional history is by its nature patriarchal, then no valuable counter-critical account can originate in mourning the loss of the father. Joan Irvine Smith is similarly criticized for a phony nostalgia that is the indulgence of the class position that her father's history bequeathed her. Smith comments wistfully: "'There is more nostalgia for me in these paintings than in actually going out to look at what used to be the ranch now that it has been developed"' (Didion 97). In fact, argues Didion trenchantly, Smith had a significant investment in "the obliteration of the undeveloped California on display at the Irvine Museum" (98). That is to say, Smith was 
complicit in the renunciation of precisely the history that she mourns. Didion's critique of both women's accounts of history exposes their nostalgia as implicated in a patriarchal class politics that perpetuates phony myths of California underwritten by their fathers. Didion's critique of their historical accounts is thus a significant part of the creative feminist history that her memoir is engaged in imagining.

28 The final significant point of origin in Where I Was From is Didion's appraisal of her own first novel Run River (1963), which she regards as having been guilty of "a tenacious (and, as I see it now pernicious) mood of nostalgia" (160). Nostalgia is a form of alienation or "protective distance" from the present (169) that she could not properly recognize at the time of its writing, and she now seeks to recover a different history from its re-appraisal. Clearly, it was a defining moment in her career as a novelist, and Didion returns to it as a further point of origin which is embroiled in the politics of representations of history. What novelist offers an indictment of her own first fiction as an integral part of her understanding of herself historically? The same author whose relation to her past is so fraught that she dismisses a scholarly book about California history simply "on discovering that I was myself quoted" (17). Even here, in a memoir largely devoted to a critical appraisal of the cultural merits of recurring patterns of historical renunciation, we witness a similar habit of abrupt repudiation. For Didion, understanding her first novel as the product of traumatic experience is a way to understand it differently in history, and thereby to conceive of a different history that originates with it. Critical engagements with the politics of nostalgia therefore hold out the possibility of creating a redemptive history.

29 In a very adroit analysis of ideas about history in Run River, Krista Comer uncovers some subtle and complex representations of temporality, class politics and gender, to show how social politics are a function of narratives of history. For Comer, Run River is a textual site where anxieties about what constitutes authentic California are played out in terms of struggles over historical knowledge. On one hand the "new" Californians of the novel are depicted as "inauthentic participants in the California story," and in this respect we can see the novel as a nostalgic lament that is patently "a refusal of the present" (74). But simultaneously the novel "relentlessly exposes the contradictions and romanticization of the past" in ways that are powerfully antinostalgic (75). The subtlety of Didion's first novel consists partly of its fastidious attempts not to conceal contradiction but to find a version of the American West "upon which to narrate stories that are not forever choices between female and western (or counter-western) sensibilities" (77). The challenging creative tension between these mutually-exclusive categories gives Run River its value to contemporary debates about conceptualizations of Western history. The novel's understanding of history is essentially male, and it has a central female protagonist who is struggling to come to terms with her exclusion. But the novel is also strongly retrospective: although it was published in 1963, Run River is set decisively in the period 1938-59, and it thereby ends before the social changes of the 1960s, which, in a sense, it does not have to address. Feminism is not yet a possibility for Lily McClellan. Historicizing the novel thus distances any gender politics that it might have engaged with more directly and explicitly. In this respect Run River is complicit in the very politics of history that it is devoted to subverting, a problem which, to a lesser extent, haunts Where I Was From.

Published just three years after Comer's, William Handley's analysis of Run River concurs that the novel's representations of history are integral to its Western politics, 
and that its struggles to identify authentic history are understood by the novel's protagonist, Lily, to be crucial to the social hierarchies of California. Handley argues that "Didion's is a complicated form of nostalgia because it puts into question the reality of the past that is longed for" (197). This is consonant with contemporary theories of nostalgia. Svetlana Boym, for example, distinguishes nostalgia from melancholy, and argues that "the danger of nostalgia is that it tends to confuse the actual home and the imaginary one and [therefore] tantalizes us with its fundamental ambivalence" (xvi-xvii). Susan Stewart similarly identifies this ambivalence when she argues that "nostalgia is the repetition that mourns the inauthenticity of all repetitions and denies the repetition's capacity to define identity" (69). Handley is therefore correct to recognize the politics that accompanies Didion's novel's scrutiny of competing historical narratives, and he argues that "The Sacramento Valley never was an Anglo-Eden except in the minds of those who hold in disdain the ethnic groups who have an equally long, if not longer, regional history" (198). Handley therefore disputes Comer's interpretation of the class politics of the novel: "It thus misses the point of the critique of Run River to argue that it "consolidates the offensive against civil rights" (199). Both Comer and Handley recognize the complexity of the historical consciousness of Run River and its conceptualizations of nostalgia. They are encouraged in this by the novel itself, which works hard to have it both ways. It is precisely this paradox of historical consciousness(of wanting to interrogate nostalgia, but in an historical novel that is itself structurally nostalgic) that makes a novel from 1963 still valuable to critics of Western fiction fifty years later, despite Didion's own caustic assessment of it. This paradox is analogous to those moments in Where I Was From which seek to interrogate the validity of moments of origin, partly by proposing alternative moments that cannot entirely escape the forms of rigorous historicizing that Didion is herself so good at.

A sfinal significant contribution to the project of recovering a concept of unmediated historical reference from post-structuralist theory can be found in Cathy Caruth's theory of trauma. Trauma theory is closely affiliated to conceptualizations of both origins and nostalgia because it seeks to establish a point of beginning from which an authentic narrative of history might have its genesis. Caruth establishes her own conceptual origins partly by returning to Paul de Man's "The Resistance to Theory," and to the problem of "how to refer to falling," which is of course a vital origin story in its own right, and one which constitutes "the original insight of his theory" $(76,74)$. Caruth's trauma theory also has its origins in a critical reading of Freud, where she identifies two further points of origin: the exodus of the Jews that Freud characterizes in "Moses and Monotheism," and, simultaneously, in the way that she historicizes Freud's text in terms of his own escape from Vienna to London in 1934. Thus upheaval and departure (Exodus) are significant points of origin both for Freud and for Caruth's interpretation of Freud, so that she can argue that "Freud resituates the very possibility of history in the nature of traumatic departure" (15). History is defined as our knowledge of the experience of trauma as a defining origin.

It is important to recognize an historical distinction that is central to the nature of trauma:

Trauma is not locatable in the simple violent or original event in an individual's past, but

rather in the way that its very unassimilated nature-the way it was precisely not known 
in the first instance-returns to haunt the survivor later on (Caruth 4). cannot be recognized as such at the time, but only identified as part of a historical narrative retrospectively. The origin is the source of a history that can only be the product of the contemporary moment; it is understood as history and in history. Thus the compulsive repetitions and historical abandonments throughout Didion's memoir, what Caruth's theory might designate "the textual itinerary of insistently recurring words or figures" (69) can be understood as symptomatic of Didion's concerted attempts to recover a history that is always just at the limit of possession and representation. Repetition, like the accumulation of stitches in her great grandmother's quilt, becomes the very style of a desire for a lost origin, and the expression of the traumatic history attendant upon that loss. Therefore history becomes almost impossible to articulate in traditional or conventional ways, and Where I Was From is an account of "misapprehensions and misunderstandings so much a part of who I became that I can still to this day confront them only obliquely" (Didion 18). Such an obliquity is therefore integral to the aesthetic style of the forms of historical enquiry that Didion's memoir undertakes. It is the expression of her creative attempt to discover a fulfilling sense of an origin, one that held out the possibility of providing the basis for a foundational epistemology of history, had it not been lost. It is a style this is necessarily asymmetrical and indirect because it is trying to find new creative ways to address the challenge of authentic historical knowledge, while simultaneously recognizing that project's precarious relation to nostalgia. In this respect, the aesthetic form of Didion's memoir is as important as the individual textual elucidations that it provides.

Derrida identified this moment in "The Essay on the Origin of Languages": "the displacing of the relationship with the mother, with nature, with being as the fundamental signified, such indeed is the origin of society and languages. But can one speak of origins after that?" (266). This is a question that much feminist criticism has responded to, eager to retrieve a politics of gender from post-structuralist conceptions of history. For example, Rita Felski, in her chapter on nostalgia in The Gender of Modernity (1995), argued that in representations of modernity, "woman emerges in these discourses as an authentic point of origin" (37-8), and her critique of modernity argues that nostalgia is therefore absolutely integral to its formation: "the redemptive maternal body constitutes the ahistorical other and the other of history against which modern identity is defined" (38). Felski's critique of modernity reveals how it is vitally dependent on a particular conception of the mother, the mother of the Eden myth, whose alterity represents some transcendental possibility of the guarantee of historical meaning. Susan Stewart's interpretation of nostalgia gives this desire significantly Biblical language: "the nostalgic's utopia is prelapsarian, a genesis where lived and mediated experience are one, where authenticity and transcendence are both present and everywhere" (23). Here, Stewart's diction locates the desire of the nostalgic in a full and complete return to a state of grace before the Fall, and that takes place for her "within the walled city of the maternal" (23). This faith in the maternal would appear to have redemptive potential, but as we have already seen, the crucial recognition of the value of Didion's relationships with her mother and with Quintana are depicted by her memoir in ways that problematize its veracity as a guarantor of value that is somehow beyond or outside the forms of its own textual representation. 
35 Where I Was From is a creative search for a gendered language of history, one that is conducted through a forensic examination of how historical narratives are constructed, and of how they are predicated on conceptualizations of origins that are themselves open to scrutiny. Didion is a shrewd critical reader of her texts, not only as points of origin in "our manifest destiny" (74) but in terms of how they represent their own moments of origin by which to constitute themselves in history. Didion's particular interest in origins is part of a project that seeks ultimately to establish some transcendental moment that lies outside or beyond the history that defines it. Although Didion is very accomplished at historicizing, the moment that her memoir strives to discover and articulate is one that exists beyond the limits of any existing critical enquiry's ability to historicize it. Therefore we should recognize that Didion's memoir is not simply an interrogation of history and mythology, but that it is a remarkable aesthetic product in its own right, a brilliantly succinct and engaging enquiry into the creative processes of history's textuality, and a major contribution to debates about the language of feminist history after post-structuralism. In particular, Where I Was From is a significant contribution to feminist attempts to wrest a new politics of history from the mythology of the American West; it is a work that demonstrates how the search for a feminist historiography is reliant upon the critical examination of conceptualizations of origins. Where I Was From identifies the history of Didion's relationship with her mother, with her adopted daughter, and of her own first novel, as crucial points of origin in a counter-narrative of Western mythology that recuperates women's experience. Because it is a memoir, it cannot escape the forms of its own textual representation of history, but it can make women's experience central to that history in ways that contribute significantly to a new politics of the West.

\section{BIBLIOGRAPHY}

Bellow, Saul. The Adventures of Augie March. New York: The Viking Press, 1953. Print

Bennett, Tony. Outside Literature. London: Routledge, 1990. Print.

Bloch, Ernst. Aesthetics and Politics. London: New Left Books, 1977. Print.

Boym, Svetlana. The Future of Nostalgia. New York: Basic Books, 2001. Print.

Caruth, Cathy. Unclaimed Experience: Trauma, Narrative and History. Baltimore: Johns Hopkins UP, 1996. Print.

Cohen, Percy. “Theories of Myth.” Man, 4, 1969. Print.

Comer, Krista. Landscapes of the New West: Gender and Geography in Contemporary Women's Writing. Chapel Hill: U of North Carolina P, 1999. Print.

Cubitt, Geoffrey. History and Memory. Manchester: Manchester U P, 2007. Print.

Davidson, Susan. “A Visit with Joan Didion.” E. G. Friedman (ed) Joan Didion: Essays and

Conversations. Princeton: Ontario Review P, 1984. Print. 
De Man, Paul. The Resistance to Theory. Minneapolis: U of Minnesota P, 1986. Print.

Derrida, Jacques. Of Grammatology. Baltimore: Johns Hopkins UP, 1967. Print.

Dick, Philip K. Time out of Joint. New York: J. B. Lippincott, 1959. Print.

Didion, Joan. Run River. New York: Obolensky, 1963. Print.

Didion, Joan. Play It As It Lays. New York: Farrar, Strauss and Giroux, 1970. Print.

Didion, Joan. Where I Was From: A Memoir. London: Flamingo, 2003. Print.

Doctorow, E. L. “False Documents." New American Review, 26, 1978. Print.

Eliot, T. S. Collected Poems, 1909-1962. London: Faber and Faber, 1980. Print.

Faulkner, William. Collected Stories. London: Vintage, 1995. Print.

Felski, Rita. The Gender of Modernity. Cambridge, Mass: Harvard UP, 1995. Print.

Felski, Rita. Doing Time: Feminist Theory and Postmodern Culture. New York: New York UP, 2000.

Print.

Handley, William. Marriage, Violence and the Nation in the American Literary West. Cambridge:

Cambridge UP, 2002. Print.

Hart, Frank. "Notes for an Anatomy of Modern Autobiography." New Literary History, 1/3, Spring, 1970, 485-511. Print.

Hindess, Barry. Pre-Capitalist Modes of Production. London: Routledge and Kegan Paul, 1975. Print.

Hirsch, Marianne. Family Frames: Photography, Narrative and Postmemory. Cambridge, Mass: Harvard UP, 1997. Print.

Jameson, Fredric, “Nostalgia for the Present." South Atlantic Quarterly, 88.2, 1989, 527-60. Print.

Jameson, Fredric. Postmodernism, or, The Cultural Logic of Late Capitalism. London: Verso, 1991. Print.

Lewis, Richard Warrington Baldwin. American Adam: Innocence, Tragedy and Tradition in the Nineteenth Century. Chicago: U of Chicago P, 1955. Print.

Lowenthal, David. The Past is a Foreign Country. Cambridge: Cambridge UP, 1985. Print.

Mali, Joseph. Mythistory: The Making of a Modern Historiography. Chicago: U of Chicago P, 2003. Print.

Maxwell, Marilyn. Male Rage, Female Fury: Gender and Violence in Contemporary American Fiction. Lanham, Md: University P of America, 2000. Print.

McLynn, Frank. Wagons West: The Epic Story of America's Overland Trails. London: Cape, 2002. Print. Mitchell, Jonathan. Revisions of the American Adam: Innocence, Identity and Masculinity in Twentieth Century America. London: Continuum, 2011. Print.

Peterson, Nancy. Against Amnesia: Contemporary Women Writers and the Crises of Historical Memory. Philadelphia: U of Pennsylvania P, 2001. Print.

Radstone, Suzannah. The Sexual Politics of Time: Confession, Nostalgia, Memory. London: Routledge, 2007. Print.

Ricciardi, Alessia. The Ends of Mourning: Psychoanalysis, Literature, Film. Stanford, California: Stanford UP, 2003. Print.

Rich, Adrienne. Blood, Bread and Poetry: Selected Prose. London: Virago, 1987. Print. 
Roth, Michael. Memory, Trauma, and History: Essays on Living with The Past. New York: Columbia UP, 2012. Print.

Stewart, Susan. On Longing: Narratives of the Miniature, the Gigantic, the Souvenir, the Collection. Baltimore: Johns Hopkins UP, 1984. Print.

Stephanson, Anders. Manifest Destiny: American Expansion and the Empire of Right. New York: Hill and Wang, 1995. Print.

Unruh, John. The Plains Across: Emigrants, Wagon Trains and the American West. London: Pimlico, 1992. Print.

Watkins, Claire Vaye. Battleborn. London: Granta, 2012. Print.

White, Hayden. Metahistory: The Historical Imagination in Nineteenth-Century Europe. Baltimore: Johns Hopkins UP, 1973. Print.

\section{ABSTRACTS}

This critical study situates Joan Didion's memoir Where I Was From in the context of debates about the textuality of history in contemporary culture. In particular the essay is a critical examination of Didion's interest in the concept of origins. What are the politics of historical origins, how might "true origins" be known, and how might a different understanding of such origins facilitate a feminist appraisal of Western American history? The essay argues that Didion's book is an innovative contribution to the genre of the memoir, and to the social history of California and the American West.

\section{INDEX}

Keywords: California, Didion, feminism., history, memoir, origins

\section{AUTHOR}

\section{KENNETH MILLARD}

The University of Edinburgh 